\section{Shadecovers Affect Degradation of Carbaryl on Field-grown Pakchoi}

\author{
Mari Marutani and \\ Veronica Endirveersingham
}

AdDITIONAL INDEX WORDs. Brassica rapa subsp. chinensis, enzyme-linked immunosorbent assay, ELISA, pesticide residue

Summary. The effect of shade covers on degradation of insecticide, carbaryl on field-grown pakchoi (Brassica rapa subsp. chinensis) was examined by a commercial enzyme-linked immunosorbent assay (ELISA) kit. Carbaryl at a.i. $10.6 \mathrm{~g} \cdot \mathrm{L}^{-1}(1.42 \mathrm{oz} / \mathrm{gal})$ was applied to the plants grown under five different shade treatments including control without any coverings. The experiment was arranged in a randomized complete block design with three replications. Pesticide residue on leaf tissues was examined on dates of 1,3 , $\mathbf{5}$, and 7 days after pesticide application. On all sampling dates, pesticide residue was greater with treatments with higher shade percentage. Both linear and quadratic relationship of shade (independent variable) and the concentration of remained carbaryl (dependent variable) were significant $(P<0.05)$. The half-life of carbaryl on pakchoi leaves ranged from 2 days for control to 9 days for the heaviest shade $(75 \%)$ treatment with rain protection.

$\mathrm{D}$ egradation of pesticides on field-grown crops varies depending on agro-climatic conditions (Mann and Chopra, 1969; Yadav and Jagalan, 1982). Such environmental factors include the amount of sunlight, air temperature, relative humidity, wind speed and precipitation (Crosby, 1969; Demeterio, 1983; Mitchell, 1961; Willis et al., 1996, 1988). The half-life of carbaryl was reported elsewhere ranging from nearly $\mathrm{l} d$ to more than $\mathrm{l}$

Agricultural Experiment Station, College of Agriculture and Life Sciences, University of Guam, UOG Station, Mangilao GU 96923.

The research was supported by USDA-NAPIAP project (GUA00132). This paper is a portion of a thesis submitted by V. Endirveersingham. We thank Jay Doronila, Ruben dela Cruz and Jesse Manglona for technical assistance. We also thank E. Wusstig for allowing us to use his field to conduct the experiment. month depending on the type of crops and growing conditions. In temperate regions the half-life of carbaryl on eggplant (Solanum melongena) was $6.5 \mathrm{~d}$ (Deshmukh and Lal, 1970) and only $\mathrm{l} \mathrm{d}$ in an area with tropic climate in India (Mann and Chopra, 1969). On citrus grown in the temperate region the half-life of carbaryl was $28 \mathrm{~d}$ on lemons (Citruslimon) and 42 d on oranges (Citrussinensis) (Gunther et al., 1962). On peaches (Prunuspersica), apples (Malus spp.), strawberries (Fragaria spp.) and gooseberries (Ribes grossularioides) it ranged from 7 to $10 \mathrm{~d}$ (Bogomolova, 1968; Polize et al., 1971).

Various types of polypropylene materials can be used as shade covers to protect growing leafy vegetables from high light intensity and high temperature in the tropics. The degree of shading may influence the persistence of a pesticide on plant tissues. To use an effective pest control practice and to provide fresh pesticide-free produce at market, it is important to know the degradation rate of a pesticide on plants grown in the field. This study evaluated the influence of shade covers on the degradation of carbaryl on field-grown pakchoi in the lowland humid tropics.

\section{Materials and methods}

EXPERIMENT SETUP AND PLANT SAMPLING. The experiment was conducted at a commercial farm near the Guam Agricultural Experiment Station in Yigo village, located at long. $144^{\circ} 55^{\prime} \mathrm{E}$ and lat. $13^{\circ} 33^{\prime}$ N. Pakchoi plants were seeded in trays and transplanted on soil classified as Guam cobbly clay (clayey, gibbsitic, nonacid, isohyperthermic Lithic Ustorthents). Plants were grown in 75 -cm-wide (29.5-inch) raised beds, having three rows of plants within each bed. Both the inter-row distance and the distance between plants within a row on a raised bed was $25 \mathrm{~cm}$ (9.8 inches). The distance between adjacent beds was 120 $\mathrm{cm}$ (47.2 inches). Plants were irrigated with a drip irrigation system.

Treatments included covering plants with 1) black woven polypropylene shade cloth (Takii Co. Ltd., Kyoto, Japan), 2) silver woven polypropylene shade cloth (Japan Wide Cross Co. Ltd., Tokyo, Japan), and 3) white woven polypropylene shade cloth (Teijin Co. Ltd., Osaka, Japan). A clear polyethylene film (Mitsubishi VinylCo. Ltd., Tokyo, Japan) was placed to shelter plants before setting up these shadecloth treatments. This film prevented the rain from washing carbaryl off the plants. The fourth treatment used only a polyethylene film to cover plants. A treatment without any covers was also included as control. All covering materials were placed on top of wire tunnel frame with a height of $75 \mathrm{~cm}$ and the width of $150 \mathrm{~cm}$ (59.1 inches).

The experiment was arranged in a randomized complete block design with five treatments and three replications. Each plot consisted of average of 30 plants with the range of 28 to 32 plants. Before the experiment, two mature leaves from each plot were tested to confirm the absence of carbaryl on plants by ELISA kit (Strategic Diagnostic Inc., Newton, Pa.).

At 1200 HR on 3 Sept. 1999, the light intensity, air temperature and relative humidity under each shade treatment were recorded (Table 1 ). Both the light intensity and the relative humidity were measured for each plot and one measurement of air temperature was taken for each treatment. The light intensity was recorded with a quantum meter (Spectrum Technologies, Inc., Plainsfield, Ill.). The percent of shade under each treatment was determined the control without any coverings as the reference of $0 \%$ shade. The air temperature and the relative humidity were measured with a hygro-thermometer clock (Cole Parmer, Vernon Hills, Ill.).

Daily rainfall and air temperature data were also recorded at an open field near the experimental site at $1200 \mathrm{HR}$ during 3 to 10 Sept. 1999 (Fig. 1). Rainfall data was taken reading a rain gauge that was set up at $1200 \mathrm{HR}$ on 2 Sept. 1999.

Carbaryl at a.i. $10.6 \mathrm{~g} \cdot \mathrm{L}^{-1}$ (Sevin 80S; Bayer CropScience, Research Triangle Park, N.C.) was applied on 4-week-old transplants with 8 to 10 mature leaves at about $1700 \mathrm{HR}$ on 3 Sept. 1999. The insecticide was mixed with deionized water and applied at a water equivalent of $935.4 \mathrm{~L} \cdot \mathrm{ha}^{-1}(100$ gal/acre). A backpack sprayer with diaphragm pump [413.7 kPa (60 lb/ inch $\left.{ }^{2}\right)$ ] and a fine flat fan nozzle was used. A pH of the pesticide solution after mixing was 7.7 and the temperature was $29^{\circ} \mathrm{C}\left(84.2^{\circ} \mathrm{F}\right)$. Within an hour after the pesticide application, two fully expanded leaves were sampled from each plot, labeled as 0 DAP (days after pesticide application). Each sample was stored in a cooler, and carbaryl level was measured within $6 \mathrm{~h}$ using an ELISA kit (Strategic Diagnostics, Inc.). With the 
Table 1. Light intensity, percentage of shade, air temperature, and relative humidity recorded for each cover treatment at Yigo, Guam, at $1200 \mathrm{HR}$ on $3 \mathrm{Sept} .1999 ;{ }^{\circ} \mathrm{F}=1.8\left({ }^{\circ} \mathrm{C}\right)+32$.

\begin{tabular}{lcccc}
\hline & $\begin{array}{c}\text { Light } \\
\text { intensity } \\
\text { Treatment }\end{array}$ & $\begin{array}{c}\text { Shade } \\
(\boldsymbol{\mu})\end{array}$ & $\begin{array}{c}\text { Air } \\
\text { temp } \\
\left(\mathbf{~}^{-2} \cdot \mathbf{s}^{-1}\right)\end{array}$ & $\begin{array}{c}\text { Relative } \\
\text { humidity } \\
(\%)\end{array}$ \\
\hline Black shade + clear plastic & $461 \pm 17.6$ & 75 & 28.1 & $77 \pm 0.5$ \\
Silver shade + clear plastic & $815 \pm 74.9$ & 56 & 28.5 & $77 \pm 0.3$ \\
White shade + clear plastic & $1243 \pm 180.6$ & 33 & 29.1 & $78 \pm 0.7$ \\
Clear plastic only & $1611 \pm 196.2$ & 13 & 30.0 & $79 \pm 0.3$ \\
No covers (control) & $1850 \pm 176.9$ & 0 & 32.0 & $80 \pm 0.5$ \\
\hline
\end{tabular}

The values for light intensity and relative humidity represent the mean and the standard deviation of three replications. The percent (\%) of shade was calculated by the equation, $100-$ (light intensity of a shade treatment) $/($ light intensity of control $) \times 100$.

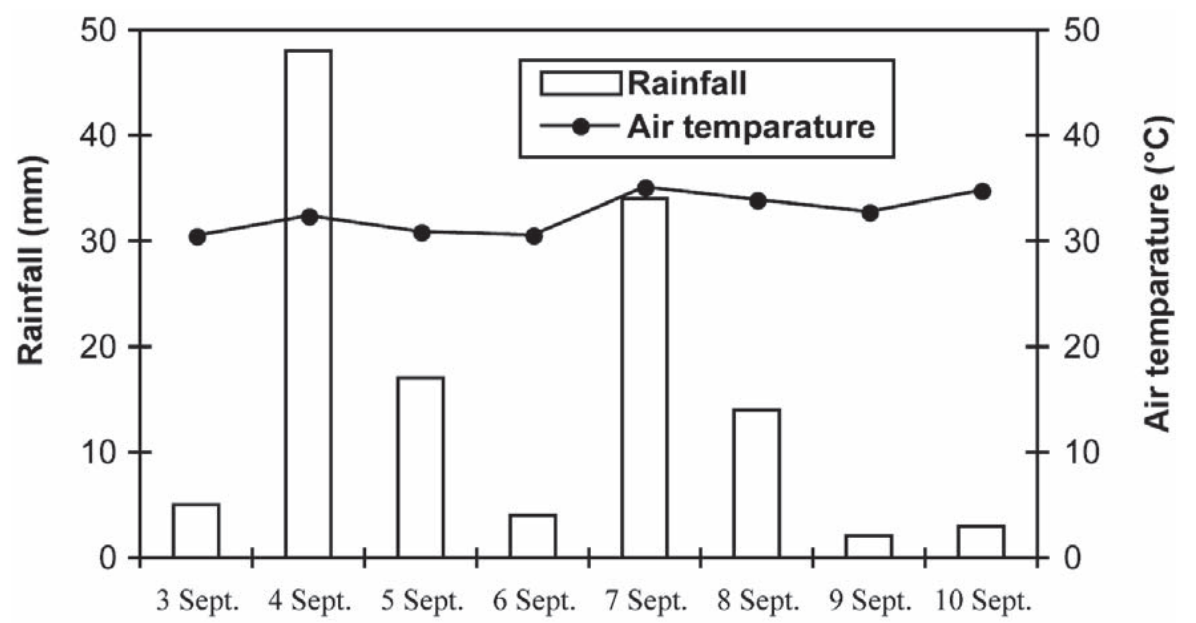

Date

Fig. 1. Rainfall and air temperature recorded at the experimental field (Yigo, Guam) at $1200 \mathrm{HR}$ from 3 to 10 , Sept. $1999 ; 25.4 \mathrm{~mm}=1.0 \mathrm{inch},{ }^{\circ} \mathrm{F}=1.8\left({ }^{\circ} \mathrm{C}\right)+32$.

same method, two fully expanded leaves sprayed with carbaryl were sampled from each plot on $1,3,5$ and 7 DAP to determine the pesticide residue.

ENZYME-LINKED IMMUNOSORBENT ASSAY FOR CARBARYL. Ten grams of composite fresh leaf samples was homogenized in $20 \mathrm{~mL}$ of acetone at the medium speed for $60 \mathrm{~s}$ with a homogenizer (Cole-Parmer). The top 4-mL acetone layer of homogenate was transferred to a tube containing 1 to 2 $\mathrm{g}$ of polyvinylpolypyrrolidone (PVPP) (Sigma Chemical Inc. St. Louis, Mo.) and vortexed for $15 \mathrm{~s}$. Two grams of salt reagent (Strategic Diagnostics, Inc.) was then added to each tube and allowed to stand for $5 \mathrm{~min}$ for the acetone aqueous phases to separate. The acetone top layer $(50 \mu \mathrm{L})$ was transferred into a 13 $\times 100 \mathrm{~mm}$ glass tube and was evaporated to dryness using nitrogen gas. The sample was redissolved in $2.5 \mathrm{~mL}$ of RaRID assay sample diluent (Strategic Diagnostics, Inc.) and stored at $4{ }^{\circ} \mathrm{C}$ $\left(39.2^{\circ} \mathrm{F}\right)$.

Carbaryl antibody coupled paramagnetic particle solution $(500 \mathrm{uL})$ (Strategic Diagnostics, Inc.) was added to each test tube containing $200 \mathrm{uL}$ of sample and $250 \mathrm{uL}$ of carbaryl enzyme conjugate (Strategic Diagnostics, Inc.). After vortexing for 1 to $2 \mathrm{~s}$, the content was incubated for $20 \mathrm{~min}$ at room temperature of $25^{\circ} \mathrm{C}\left(77.0^{\circ} \mathrm{F}\right)$ and was placed in a magnetic separation rack for $2 \mathrm{~min}$. The solution was decanted and the sample was washed twice with $1 \mathrm{~mL}$ of buffer solution (Strategic Diagnostics, Inc.). Color solution $(500 \mu \mathrm{L})$ (Strategic Diagnostics, Inc.) containing hydrogen peroxide and 3,3 ', 5, 5'-tetramethylbenzidine was added to the sample, vortexed for 2 $\mathrm{s}$, and incubated at room temperature for $20 \mathrm{~min}$. The amount of carbaryl in each sample was recorded within 15 min after adding $500 \mu \mathrm{L}$ of stopping reagent (Strategic Diagnostics, Inc.) using a spectrophotometer at $450 \mathrm{~nm}$ (U-2000; Hitachi High Technologies, San Jose, Calif.).

Data analysis. The half-life of carbaryl was calculated as described by Aly and El-Dib (1971) and Denton et al. (1995). After log transformation, the concentration of the pesticide (dependent variable) was plotted against the date of sampling (independent variable) for each shade treatment. The half-life of carbaryl was then calculated using the equation, $t_{1 / 2}=0.693 / \mathrm{K}$, where $\mathrm{t}_{1 / 2}=$ the time taken for $50 \%$ of the pesticide to degrade and $\mathrm{K}=$ the rate loss constant. The value Kwas obtained after multiplying the slope of the regression equation by 2.303 (Aly and El-Dib, 1971).

The slopes of $\log$ transformed regression lines for all treatments were compared by an analysis of covariance (ANCOVA) (Snedecor and Cochran, 1967; Sokal and Rohlf, 1969). The analysis of covariance revealed that both the level of shade (a factor) and the number of days after carbaryl application (a covariate) might affect the amount of pesticide residue on plant tissues (dependent variable). A posthoc test (Student-Newman-Keuls test) was applied to determine the degree of similarity of the slopes of regression lines affected by the shade treatment at 0.05 probability level.

The shade treatments were also compared on each sampling date by subjecting the original data to analysis of variance (ANOVA). Treatment means were also compared by a post hoc test (Fisher's protected least significant difference) at 0.05 probability level. On each examined dates of 1,3 , 5 , and $7 \mathrm{DAP}$, both linear and quadratic regression equation of carbaryl residue (dependent variable) against the percentage of shade cover (independent variable) were determined to study the relationship of two variables. All analyses were conducted using StatView version 5.01 (SAS Institute, 1998).

\section{Results and discussion}

The half-life of carbaryl on fieldgrown pakchoi ranged from 2 to 9 $\mathrm{d}$ depending on the shade treatment (Table 2). In the open field with $0 \%$ shade (control), the half-life of carbaryl was the shortest with $2 \mathrm{~d}$. The half-life of carbaryl was $9 \mathrm{~d}$ under shade treatments 
Table 2. The half-life of carbaryl on pakchoi leaves grown at Yigo, Guam, under each cover treatment. Carbaryl at a.i. $10.6 \mathrm{~g} \cdot \mathrm{L}^{-1}(1.42 \mathrm{oz} / \mathrm{gal})$ was applied on 4-week-old transplants on 3 Sept. 1999.

\begin{tabular}{lcc}
\hline Treatment & $\begin{array}{c}\text { Shade } \\
(\%)\end{array}$ & $\begin{array}{c}\text { Half-life } \\
\text { of carbaryl } \\
\text { (d) }\end{array}$ \\
\hline Black shade + clear plastic & 75 & 9 \\
Silver shade + clear plastic & 56 & 8 \\
White shade + clear plastic & 33 & 6.5 \\
Clear plastic only & 13 & 4 \\
No covers (control) & 0 & 2 \\
\hline
\end{tabular}

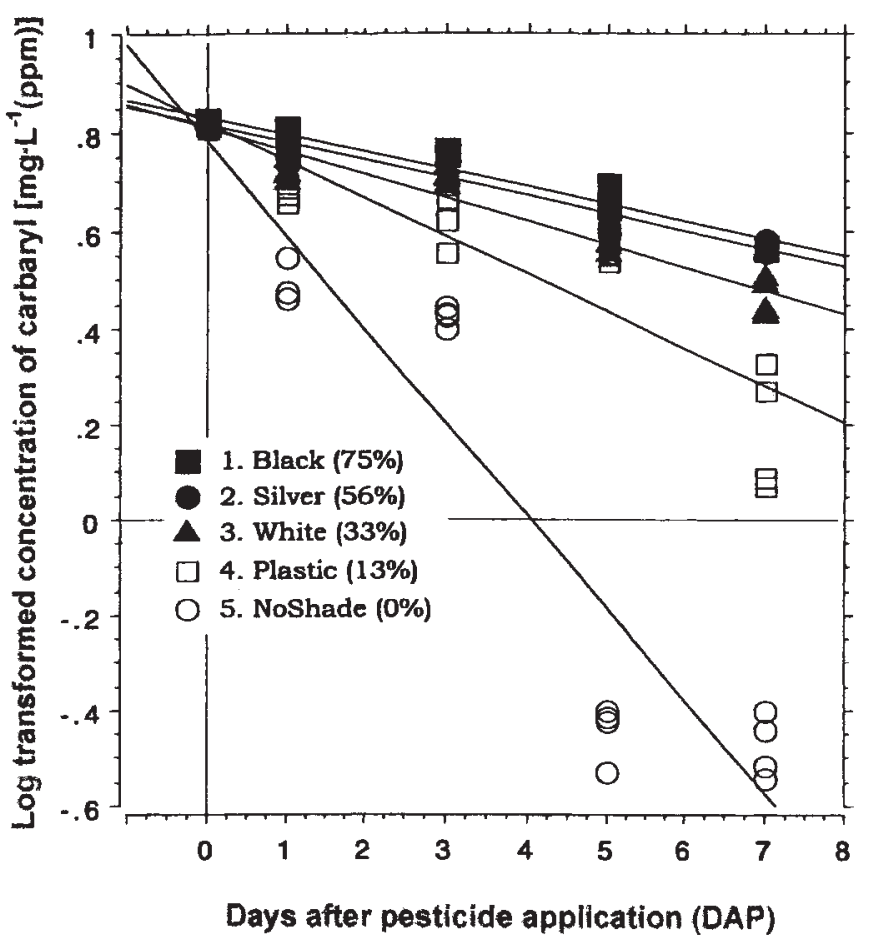

\begin{tabular}{lccc}
\hline Treatment & Shade (\%) & Regression equation & $x^{2}$ \\
\hline 1. Black shade + clear plastic & 75 & $\mathrm{Y}=(0.035) \mathrm{X}+0.832$ & 0.935 \\
2. Silver shade + clear plastic & 56 & $\mathrm{Y}=(0.036) \mathrm{X}+0.815$ & 0.921 \\
3. White shade + clear plastic & 33 & $\mathrm{Y}=(0.047) \mathrm{X}+0.810$ & 0.931 \\
4. Clear plastic only & 13 & $\mathrm{Y}=(0.077) \mathrm{X}+0.821$ & 0.818 \\
5. No shade & 0 & $\mathrm{Y}=(0.194) \mathrm{X}+0.784$ & 0.896 \\
\hline & & \\
\hline
\end{tabular}

Fig. 2. Log-transformed concentration of carbaryl detected on pakchoi leaves on $0,1,3,5$ and $7 \mathrm{~d}$ after pesticide application (DAP). Each linear regression line presents the relationship of pesticide residue and DAP for each treatment. The active ingredient of carbaryl at a.i. $10.6 \mathrm{~g} \cdot \mathrm{L}^{-1}(1.42 \mathrm{oz} / \mathrm{gal})$ was applied on 4week-old transplants on 3 Sept. 1999.

of the black cloth + plastic cover $(75 \%$ shade), $8 \mathrm{~d}$ for the silver cloth + plastic cover ( $56 \%$ shade), $6.5 \mathrm{~d}$ for the white cloth + plastic cover (33\% shade), and $4 \mathrm{~d}$ for the treatment of plastic cover only ( $13 \%$ shade).

Since the linear regressions of log-transformed carbaryl amount (dependent variable) against DAP (independent variable) were significant for all shade treatments (Fig. 2), the analysis of covariance was conducted to measure a similarity of those regression equations as an influence of the shade treatment. The analysis revealed that the treatment affected the slopes of regression lines, suggesting that shading influenced the rate of carbaryl breakdown on plant tissues. The results from a post hoc test revealed that the slopes of regression lines for the $75 \%$ and $56 \%$ shade treatments were not significantly different $(P$ $=0.787$ ) suggesting that the breakdown rate of the insecticide was very similar under the two highest shade covers. Likewise the slopes of regression lines for the $56 \%$ and $33 \%$ shade treatments were not significantly different $(P=$ $0.115)$. All other pair comparisons of shade treatments showed that the slopes of the regression lines were significantly different $(P<0.05)$ suggesting that $\%$ shade was a factor influenced the rate of chemical loss from plant tissues. Control without any covers had the most rapid loss of carbaryl, followed by the $13 \%$ shade cover where plants were grown under clear plastic cover only.

The ANOVA was also conducted to determine an effect of shade treatments on pesticide residue for each sampling date (Table 3). On all sampling dates, the mean carbaryl concentration was highest for the $75 \%$ shade treatment. This value was not significantly different from the carbaryl concentrations detected from the $56 \%$ treatment of (Table 3). On 1 DAP plants grown under the $75 \%$ and $56 \%$ shades retained more than $90 \%$ of the original amount of carbaryl, recording $6.08 \mathrm{mg} \cdot \mathrm{L}^{-1}$ (ppm) and $5.70 \mathrm{mg} \cdot \mathrm{L}^{-1}$, respectively. On the other hand, the least amount of the pesticide $\left(3.10 \mathrm{mg} \cdot \mathrm{L}^{-1}\right)$ was detected from leaves of plants grown under the control. Chemical loss in the control seemed to be due to both light and rain wash off. Nearly $48.3 \mathrm{~mm}$ ( 2 inches) of rainfall recorded during $24 \mathrm{~h}$ between the pesticide application and the first sampling time (Fig. 2) possibly accelerated the pesticide loss for control on 1 DAP. The breakdown of the insecticide on plants without covers was very rapid having only $0.36 \mathrm{mg} \cdot \mathrm{L}^{-1}$ of carbaryl detected in plant tissues on $5 \mathrm{DAP}$.

Under other four cover treatments ranging from $13 \%$ to $75 \%$ shade, the pesticide loss due to the rainfall was prevented by the protective plastic covering. Data in Table 3 exhibits that as the percentage of shade increased, the higher concentration of carbaryl remained on plants on all sampling dates. When regression analyses were applied, it was found that on each examined dates of $1,3,5$, and 7 DAP, both linear and quadratic regression equation of carbaryl residue (dependent variable) against the percentage of shade cover (independent variable) were highly significant $(P<0.001)$.

The study clearly showed that the 
Table 3. Mean carbaryl concentration $(n=3)$ recovered from pakchoi grown at Yigo, Guam, under each cover treatment on $1,3,5$, and $7 \mathrm{~d}$ after pesticide application (DAP). Carbaryl at a.i. $10.6 \mathrm{~g} \cdot \mathrm{L}^{-1}(1.42 \mathrm{oz} / \mathrm{gal})$ was applied on 4 -week-old transplants on 3 Sept. 1999.

\begin{tabular}{|c|c|c|c|c|c|}
\hline \multirow[b]{2}{*}{ Treatment } & \multirow{2}{*}{$\begin{array}{c}\text { Shade } \\
(\%)\end{array}$} & \multicolumn{4}{|c|}{ Concn of carbaryl recovered $\left[\mathrm{mg} \cdot \mathrm{L}^{-1}(\mathrm{ppm})\right]$} \\
\hline & & $1 \mathrm{DAP}$ & 3 DAP & 5 DAP & 7 DAP \\
\hline Black shade + clear plastic & 75 & $6.08 \mathrm{a}$ & $5.78 \mathrm{a}$ & $4.70 \mathrm{a}$ & $3.68 \mathrm{a}$ \\
\hline Silver shade + clear plastic & 56 & $5.70 \mathrm{a}$ & $5.61 \mathrm{a}$ & $4.02 \mathrm{ab}$ & $3.73 \mathrm{a}$ \\
\hline White shade + clear plastic & 33 & $5.25 \mathrm{~b}$ & $5.15 \mathrm{a}$ & $3.72 \mathrm{~b}$ & $2.95 \mathrm{a}$ \\
\hline Clear plastic only & 13 & $4.80 \mathrm{c}$ & $4.34 \mathrm{ab}$ & $3.56 \mathrm{~b}$ & $1.60 \mathrm{~b}$ \\
\hline No covers (control) & 0 & $3.10 \mathrm{~d}$ & $2.66 \mathrm{~b}$ & $0.36 \mathrm{c}$ & $0.34 \mathrm{~b}$ \\
\hline Average & & 4.99 & 4.71 & 3.27 & 2.46 \\
\hline
\end{tabular}

Means followed by the same letter within each DAP are not significantly different by the Fisher's protected least significant difference at $P=0.05$.

amount of carbaryl residue detected on pakchoi leaves was greatest under the darkest shade cover. The combined environmental factors of sunlight (Table 1) and precipitation (Fig. 1) might have intensified the reduction of the pesticide on plants grown without any coverings. The reduced light penetration plus no rain effects led to longer half-life of the insecticide under the shade covers.

This result complements reports of faster degradation of two insecticides, malathion and diazinon, on okra ( $\mathrm{Abel}$ moschus esculentus) and sweet pepper (Capsicum annuum) when grown in open field on Guam compared to those plants grown in shaded area (Demeterio, 1981 and 1983). The result of the present study also agrees with the report by Crosby (1969) indicating that light intensity greatly influenced pesticide degradation. It is probable that since the shade covers lowered the penetration of light, the lower light intensity was responsible for a reduction in the rate of volatilization and hydrolysis of the pesticide, thus resulting in prolonging the pesticide presence.

This study concluded that carbaryl degraded faster in an open-field compared to low light intensity treatments in the tropics. Understanding that the fate of a pesticide depends greatly on a plant's growing environment enables more effective pest management practices.

\section{Literature cited}

Aly, O.M. and M.A. El-Dib. 1971. Studies on the persistence of some carbamate insecticides in the aquatic environment. I. Water Res. 5: 1191-1205.

Bogomolova, Z.N. 1968. Sevin stability in fruit and berry crops during vegetation and prolonged storage. Voprosy Pitaniya 27:55.

Crosby, D.G. 1969. Experimental approaches to pesticide photodecomposition. Residue Rev. 25:1-12.

Crosby, D.G., E. Leitis, and W.L., Winterlin. 1965. The photodecomposition of carbamate insecticides. J. Agr. Food Chem. 13: 204-207.

Demeterio, J.L. 1981. Pesticide residue. p. 25-30 In: Annual report: Guam Agricultural Experiment Station, Mangilao.

Demeterio, J.L. 1983. Diazinon degradation in field and greenhouse conditions, p. 1-9. In: Annual report. Guam Agr. Expt. Sta., Mangilao.

Denton, G.R.W., H.R. Wood, and J. McConnell. 1995. Mobility and persistence of chloypyrifos in a tropical soil under simulated field conditions adopting a high watering regime. Proc. Amer. Water Resour. Assn. Annu. Summer Symp. Honolulu, p. 403-413.

Deshmukh, S.N. and R. Lal. 1970. Dissipation of carbaryl residues from brinjal ( Solanum melongena L.) plants. Indian J. Entomol. 32: 201

Gunther, F.A., R.C. Blinn, and G.E. Carman. 1962. Residues of Sevin on and in lemons and oranges. J. Agr. Food Chem. 10:222-223.

Mann, G.S. and S.L. Chopra. 1969. Residues of carbaryl on crops. Pesticides Monitoring J. 2:163-166.

Mitchell, L.C. 1961. The effect of ultraviolet light on 141 pesticide chemicals by paper chromatography. J. Assn. Official Agr. Chem. 44:643.

Polizu, A., H. Gregor, and A.V. Alexandri. 1971. Studies on the persistence of carbaryl residues in fruit. Qualitas Plantarum et Materiae Vegtabiles 20:215-220.

SAS Institute. 1998. StatView v. 5.01: SAS/ STAT user's guide. 2nd ed. SAS Inst., Cary, N.C.

Snedecor, G.W. and W.G. Cochran. 1967. Statistical Methods. 6th ed. Iowa State Univ. Press, Ames.

Sokal, R.R. and J. Rohlf. 1969. Biometry. Freeman, San Francisco.

Willis, G.H., L.L. McDowell, S. Smith, and L.M. Southwick. 1988. Rainfall amount and intensity effect on carbaryl wash off from cotton plants. Trans. Amer. Soc. Agr.Eng. 31:86-90.

Willis, G.H., S. Smith, L.L. McDowell, and L.M. Southwick. 1996. Carbaryl wash off from soybean plants. Arch. Environ. Contam. Toxicol. 31:239-243.

Yadav, P.R. and R.S. Jagalan. 1982. Persistence of carbaryl residues in and on unprocessed and processed cauliflower curds. Beitrage zur Tropischen Landwirtschaft und Veterinaermedizin 20:89-95. 